\title{
Data Mining Untuk Menganalisa Pola Pembelian Perak Dengan Menggunakan Algoritma Fp-Growth Pada Toko Emas Dan Perak Adi Saputra Tanjung
}

\author{
Latifa Suryani Nasution, Widiarti Rista Maya, Jufri Halim, Marsono \\ Program Studi Sistem Informasi, STMIK Triguna Dharma \\ JI. A.H Nasution No.73 Medan, Sumatera Utara, 20142
}

\begin{abstract}
Abstrak
Pencatatan data transaksi pembelian perak harian pada took emas dan perak Adi Saputra Tanjung belum dilakukan dengan rapi dan data transaksinya dicatat ke dalam buku besar masih secara manual sehingga membuat pemilik toko kesulitan dalam menentukan barang apa saja yang laris di tokonya yang mengakibatkan promosi yang digunakan untuk meningkatkan penjualan di nilai kurang maksimal.

Berdasarkan penelitian sebelumnya yang ditulis oleh Agus Nuryanto yaitu Penerapan Data Mining Menggunakan Algoritma Apriori Dan K-Means Untuk Meningkatkan Penjualan Toko Perhiasan Emas Setia Kawan, peneliti menganalisa pola pembelian perak untuk penemuan pola barang yang dibeli oleh pelanggan dengan harapan hasil penelitian dapat membantu rekomendasi promosi sehingga strategi pemasaran menjadi lebih tepat sasaran. algoritma yang digunakan adalah Frequent Pattern- Growth (FP-Growth) yaitu pengembangan dari metode Apriori yang merupakan salah satu alternatif untuk menentukan himpunan data yang paling sering muncul (frequent itemset) dalam sebuah kumpulan data dengan membangkitkan struktur data Tree atau disebut dengan Frequent Pattern Tree (FP-Tree).

Hasil penelitian dari tahapan yang telah dilakukan, didapatkan nilai support sebesar $9 \%$ dan nilai confidence sebesar $30 \%$ dengan jenis perak yang dibeli konsumen yaitu cincin putar, mainan kalung, kalung nama, cincin rantai pilin dan anting. Hasilnya dapat membantu pemilik toko untuk mengambil keputusan dalam penentuan stok perak yang perlu diperbanyak sehingga meningkatkan keuntungan dan meminimalisir kerugian.
\end{abstract}

Kata kunci : Data Mining, Asosiasi, Frequent Itemset, FP-Tree, FP-Growth

\begin{abstract}
The recording of daily silver purchase transaction data on Adi Saputra Tanjung gold and silver took has not been done neatly and the transaction data is recorded into the ledger still manually making it difficult for the store owner to determine what goods are selling in his store which resulted in the promotion used to increase sales at less maximum value.

Based on previous research written by Agus Nuryanto, namely The Application of Data Mining Using Apriori And K-Means Algorithms to Increase Sales of Setia Kawan Gold Jewelry Stores, researchers analyzed silver purchasing patterns for the discovery of patterns of goods purchased by customers in the hope that the results of the study can help promotional recommendations so that marketing strategies become more targeted. The algorithm used is Frequent Pattern- Growth (FP-Growth) which is the development of the Apriori method which is one of the alternatives to determining the most frequent itemset in a data set by generating a Tree data structure or so-called Frequent Pattern Tree (FP-Tree).

The results of the research from the stages that have been done, obtained support value of $9 \%$ and confidence value of $30 \%$ with the type of silver purchased by consumers namely rotary rings, toy necklaces, name necklaces, twist chain rings and earrings. The results can help store owners to make decisions in determining silver stock that needs to be expanded so as to increase profits and minimize losses.
\end{abstract}


Keywords : Data Mining, Asosiasi, Frequent Itemset, FP-Tree, FP-Growth

\section{PENDAHULUAN}

Pada tabel periodik, perak memiliki lambang Ag dengan nomor atom 47. Perak merupakan logam transisi lunak berwarna putih dan mengkilap dan merupakan salah satu logam mulia yang tidak mengalami proses korosif, memiliki nilai jual tinggi. Selain emas, perak sering digunakan sebagai bahan membuat perhiasan dikarenakan harganya yang relatif lebih murah. Meskipun relatif lebih murah, perak merupakan salah satu barang investasi yang bernilai tinggi dan merupakan salah satu bahan alternatif pembuat kalung, cincin, dan gelang selain emas.

Toko emas dan perak Adi Saputra Tanjung beralamat di pasar gunung tua. Toko emas dan perak adi saputra tanjung bergerak di bidang transaksi jual beli perhiasan seperti: cincin, kalung, gelang, liontin dengan beragam model. Pencatatan data transaksi pembelian perak harian belum dilakukan dengan rapi dan data transaksinya dicatat ke dalam buku besar masih secara manual sehingga membuat pemilik toko kesulitan dalam menentukan barang apa saja yang laris di tokonya yang mengakibatkan promosi yang digunakan untuk meningkatkan penjualan di nilai kurang maksimal.

Dalam penelitian ini akan dibuat pola pembelian perak pada toko emas dan perak Adi Saputra Tanjung dengan metode Asosiasi, berdasarkan penelitian sebelumnya yang ditulis oleh Agus Nuryanto yaitu Penerapan Data Mining Menggunakan Algoritma Apriori Dan K-Means Untuk Meningkatkan Penjualan Toko Perhiasan Emas Setia Kawan [1] peneliti menganalisa pola pembelian perak untuk penemuan pola barang yang dibeli oleh pelanggan dengan harapan hasil penelitian dapat membantu rekomendasi promosi sehingga strategi pemasaran menjadi lebih tepat sasaran. Berdasarkan nilai support dan confidence yang di tentukan nantinya dapat digunakan sebagai acuan promosi untuk meningkatkan penjualan toko perhiasan emas dan perak Adi Saputra Tanjung. [2]

Data mining merupakan suatu proses untuk memperoleh informasi penting yang sangat berguna dari informasi yang sebelumnya tidak diketahui dan pengetahuan yang diperoleh informasi yang berharga dan dapat dimengerti dari sebuah data. [2]

Dalam penelitian ini, algoritma yang digunakan adalah Frequent Pattern- Growth (FP-Growth) yaitu pengembangan dari metode Apriori yang merupakan salah satu alternatif untuk menentukan himpunan data yang paling sering muncul (frequent itemset) dalam sebuah kumpulan data dengan membangkitkan struktur data Tree atau disebut dengan Frequent Pattern Tree (FP-Tree). [3]

\section{Kajian Pustaka}

\subsection{Knowledge Discovery Database (KDD)}

Knowledge Discovery in Database (KDD) adalah proses menentukan informasi yang berguna serta pola-pola yang ada dalam data. Informasi ini terkandung dalam basis data yang berukuran besar yang sebelumnya tidak diketahui dan potensial bermanfaat. Data Mining merupakan salah satu langkah dari serangkaian proses KDD seperti terlihat pada gambar di bawah ini:

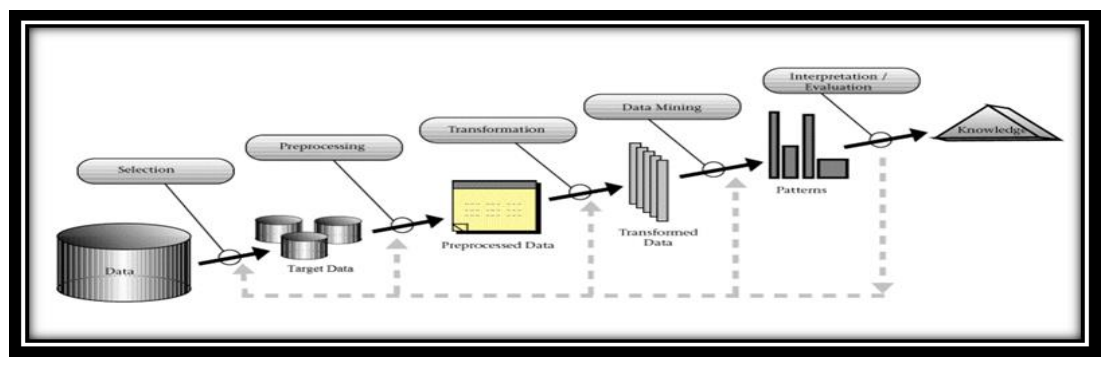




\subsection{Data Mining.}

Data mining menurut David Hand, HeikkiMannila, dan Padhraic Smyth dari MIT adalah analisa terhadap data untuk menemukan hubungan yang jelas serta menyimpulkannya yang belum diketahui sebelumnya dengan cara terkini dipahami dan berguna bagi pemilik data tersebut.

Menurut Gartner Group,data mining adalah proses menemukan hubungan baru yang mempunyai arti, pola dan kebiasaan dengan memilah-milah sebagian besardata yang disimpan dalam media penyimpanan dengan menggunakan teknologi pengenalan pola seperti teknik statistik dan matematika. Data mining merupakan gabungan dari beberapa disiplin ilmu yang menyatukan teknik dari pembelajaran mesin, pengenalan pola, statistik, database, dan visualisasi untuk penanganan permasalahan pengambilan informasi dari database yang besar (Larose,2005).

Data mining adalah proses yang menggunakan teknik statistik, matematika, kecerdasan buatan, dan machine learning untuk mengekstraksi dan mengidentifikasi informasi yang bermanfaat dan pengetahuan yang terkait dari berbagai database besar. Data mining merupakan serangkaian proses untuk menggali nilai tambah dari suatu kumpulan data berupa pengetahuan yang selama ini tidak diketahui secara manual [5].

\subsection{Fungsi Dan Tujuan Data Mining}

\section{Fungsi Data mining}

Fungsi Data mining adalah mengidentifikasi fakta- fakta atau kesimpulan-kesimpulan yang di sarankan berdasarkan penyaringan melalui data untuk menjelajahi pola-pola atau anomalianomali data. Data Mining mempunyai 5 fungsi:

1. Classification, yaitu menyimpulkan definisi karakteristik sebuah grup.

2. Clustering, yaitu mengindentifikasikan kelompok barang atau produk- yang mempunyai karakteristik khusus.

3. Association, yaitu mengidentifikasikan hubungan antara kejadian yang terjadi pada suatu waktu.

4. Sequencing Hampir sama dengan association, sequencing mengidentifikasikan hubungan yang berbeda pada suatu periode waktu tertentu.

5. Forecasting memperkirakan nilai pada masa yang akan datang berdasarkan pola data.

\section{Tujuan Data Mining}

1. Explanatory adalah untuk menjelaskan kondisi penelitian,.

2. Confirmatory adalah untuk mempertegas hipotesis,.

3. Exploratory adalah untuk menganalisis hubungan data yang baru

\subsection{Pengelompokan dan Metode Data Mining}

Pada proses pemecahan masalah dan pencarian pengetahuan baru terdapat beberapa klasifikasi secara umum yaitu:

1. Estimasi

Digunakan untuk melakukan estimasi terhadap sebuah data baru yang tidak memiliki keputusan berdasarkan histori data yang telah ada. Contohnya ketika melakukan Estimasi Pembiayaan pada saat pembangunan sebuah Hotel baru pada Kota yang berbeda.

2. Asosiasi

Digunakan untuk mengenali kelakuan dari kejadian- kejadian khusus atau proses dimana hubungan asosiasi muncul pada setiap kejadian. Adapun metode pemecahan masalah yang sering digunakan seperti Algoritma Apriori. Contoh pemanfaatan Algoritma Asosiasi yaitu pada Bidang Marketing ketika sebuah Minimarket melakukan Tata letak produk yang dijual berdasarkan Produk-produk mana yang paling sering dibeli konsumen, selain itu seperti tata letak buku yang dilakukan pustakawan di perpustakaan

3. Klasifikasi

Suatu teknik dengan melihat pada kelakuan dan atribut dari kelompok yang telah didefinisikan. Teknik ini dapat memberikan klasifikasi pada data baru dengan memanipulasi data yang ada yang telah diklasifikasi dan dengan menggunakan hasilnya untuk memberikan sejumlah aturan. Salah satu contoh yang mudah dan popular adalah dengan Decision tree yaitu salah satu metode klasifikasi yang paling populer karena mudah untuk interpretasi seperti Algoritma C4.5, ID3 dan lain-lain. Contoh 
pemanfaatannya adalah pada bidang Akademik yaitu Klasifikasi siswa yang layak masuk kedalam kelas unggulan atau akselerasi di sekolah tertentu.

4. Klastering

Digunakan untuk menganalisis pengelompokkan berbeda terhadap data, mirip dengan klasifikasi, namun pengelompokkan belum didefinisikan sebelum dijalankannya tool data mining. Biasanya menggunkan metode neural network atau statistik, analitikal hierarki cluster.Clustering membagi item menjadi kelompok- kelompok berdasarkan yang ditemukan tool data mining.

5. Prediksi

Algoritma prediksi biasanya digunakan untuk memperkirakan atau forecasting suatu kejadian sebelum kejadian atau peristiwa tertentu terjadi. Contohnya pada bidang Klimatologi dan Geofisika, yaitu bagaimana Badan Meterologi Dan Geofisika (BMKG) memperkirakan tanggal tertentu bagaimana Cuacanya, apakah Hujan, Panas dan lain sebagainya. Ada beberapa metode yang sering digunakan salah satunya adalah Metode Rough Set.

Di dalam data mining juga sama halnya dengan konsep Neural Network mengandung dua pengelompokkan yaitu:

1. Supervised Learning yaitu pembelajaran menggunakan guru dan biasanya ditandai dengan adanya Class/Label/Target pada himpunan data. Adapun metode- metode yang digunakan yang bersifat supervised learning seperti Metode Prediksi dan Klasifikasi seperti Algoritma C4.5, Metode Rough Set dan Lain-lain.

2. Unsupervised Learning yaitu pembelajaran tanpa menggunakan guru dan biasanya ditandai pada himpunan datanya tidak memiliki attribut keputusan atau Class/Label/Target. Adapun metode-metode yang bersifat Unsupervised Learning yaitu Metode Estimasi, Clustering, Dan Asosiasi seperti Regresi Linier, Analytical Hierarchy Clustering dan lain-lain. [6]

\subsection{Association Rule.}

Association rule mining adalah suatu procedure untuk mencari hubungan antar item dalam suatu data set yang ditentukan. (Han Kamber, 2001). Association rule meliputi dua tahap:

1. Mencari kombinasi yang paling sering terjadi dari suatu itemset.

2. Mendefinisikan Condition dan Result (untuk conditional association rule). (Ulmer David, 2002)

Dalam menentukan suatu association rule, terdapat suatu interesting measure (ukuran kepercayaan) yang didapatkan dari hasil pengolahan data dengan perhitungan tertentu. Umumnya ada dua ukuran, yaitu:

1. Support

suatu ukuran yang menunjukan seberapa besar tingkat dominasi suatu item/itemset dari keseluruhan transaksi. Ukuran ini menentukan apakah suatu item/itemset layak untuk dicari confidence-nya (misal, dari keseluruhan transaksi yang ada, seberapa besar tingkat dominasi yang menunjukan bahwa item A dan B dibeli bersamaan).

2. Confidence

Suatu ukuran yang menunjukkan hubungan antar 2 item secara conditional (misal, seberapa sering item B dibeli jika orang membeli item A). Kedua ukuran ini nantinya berguna dalam menentukan interesting association rules, yaitu untuk dibandingkan dengan batasan (treshold) yang ditentukan oleh user. Batasan tersebut umumnya terdiri dari min_support dan min_confidence. Contoh Suatu association rule:

If $\bar{A}$ then $B$ [support $=2 \%$, confidence $=60 \%$ ],

Dimana $A$ dan $B$ adalah kumpulan item yang dibeli oleh konsumen perusahaan $X$. Artinya : item A dan B dibeli bersamaan sebesar $2 \%$ dari keseluruhan data transaksi yang dianalisis dan $60 \%$ dari semua konsumen yang membeli item A juga membeli item B. Dari contoh di atas, jika support-nya $>=$ min_support dan confidence-nya $>=$ min_confidence, maka rule tersebut bisa dikatakan sebagai interesting rule. [6]

\subsection{Algoritma Fp-Growth.}

Algoritma FP-Growth merupakan pengembangan dari algoritma Apriori. Sehingga kekurangan dari algoritma Apriori diperbaiki oleh algoritma FPGrowth. 
Frequent Pattern Growth (FPGrowth) adalah salah satu alternatif algoritma yang dapat digunakan untuk menentukan himpunan data yang paling sering muncul (frequent itemset) dalam sebuah kumpulan data[8].

Pada algoritma Apriori diperlukan generate candidate untuk mendapatkan frequent itemsets. Akan tetapi, di algoritma FP-Growth generate candidate tidak dilakukan karena FPGrowth menggunakan konsep pembangunan tree dalam pencarian frequent itemsets. Hal tersebutlah yang menyebabkan algoritma FP-Growth lebih cepat dari algoritma Apriori.

Karakteristik algoritma FPGrowth adalah struktur data yang digunakan adalah tree yang disebut dengan FP-Tree. Dengan menggunakan FP-Tree, algoritma FP-Growth dapat langsung mengekstrak frequent itemset dari FP-Tree. Penggalian itemset yang frequent dengan menggunakan algoritma FP-Growth akan dilakukan dengan cara membangkitkan struktur data tree atau disebut dengan FP-Tree. Metode FP-Growth dapat dibagi menjadi 3 tahapan utama yaitu sebagai berikut :

1. Tahap Pembangkitan conditional pattern base,

2. Tahap pebangkitan conditional FP-Tree, dan

3. Tahap pencarian frequent itemset [7]

\section{ANALISA DAN HASIL}

\subsection{Algoritma Sistem}

Algoritma sistem merupakan penjelasan langkah-langkah penyelesaian masalah dalam pola pembelian perak dengan menggunakan algoritma FP-Growth pada toko emas dan perak adi saputra tanjung.

\subsection{Analisis Data Transaksi.}

Data transaksi yang digunakan merupakan data transaksi pembelian perak pada tanggal 1 sampai dengan 31 desember 2019. Data tersebut adalah data sampel dari data transaksi sebanyak 31 transaksi. Berikut ini adalah data yang digunakan sebagai sampel dalam penelitian ini yaitu :

Tabel 3.2 Data Transaksi

\begin{tabular}{|c|c|c|}
\hline TID & Tanggal & \multicolumn{1}{c|}{ Transaksi } \\
\hline 1 & 01 Desember 2019 & $\mathrm{~A} 1, \mathrm{~A} 13, \mathrm{~A} 2, \mathrm{~A} 3, \mathrm{~A} 15, \mathrm{~A} 20$ \\
\hline 2 & 02 Desember 2019 & $\mathrm{~A} 20, \mathrm{~A} 2, \mathrm{~A} 4, \mathrm{~A} 27, \mathrm{~A} 18$ \\
\hline 3 & 03 Desember 2019 & $\mathrm{~A} 4, \mathrm{~A} 2, \mathrm{~A} 19, \mathrm{~A} 5, \mathrm{~A} 6, \mathrm{~A} 5, \mathrm{~A} 5$ \\
\hline
\end{tabular}

Tabel Data Transaksi 3.2 (Lanjutan)

\begin{tabular}{|l|l|l|}
\hline 4 & 04 Desember 2019 & A8,A13,A14,A29 \\
\hline 5 & 05 Desember 2019 & A7,A6,A22 \\
\hline 6 & 06 Desember 2019 & A2,A15,A5,A7,A28 \\
\hline 7 & 07 Desember 2019 & A19,A19,A20,A5 \\
\hline 8 & 08 Desember 2019 & A11,A2,A9 \\
\hline 9 & 09 Desember 2019 & A13,A13,A28,A2 \\
\hline 10 & 10 Desember 2019 & A10,A4,A12,A2 \\
\hline 11 & 11 Desember 2019 & A2,A12,A2,A28,A13 \\
\hline 12 & 12 Desember 2019 & A28,A2,A10,A4 \\
\hline 13 & 13 Desember 2019 & A12,A2,A12 \\
\hline
\end{tabular}




\begin{tabular}{|l|l|l|}
\hline 14 & 14 Desember 2019 & A2,A25,A13 \\
\hline 15 & 15 Desember 2019 & A28,A4,A2 \\
\hline 16 & 16 Desember 2019 & A4,A19,A29,A13 \\
\hline 17 & 17 Desember 2019 & A2,A23,A22 \\
\hline 18 & 18 Desember 2019 & A24,A29 \\
\hline 19 & 19 Desember 2019 & A5,A5 \\
\hline 20 & 20 Desember 2019 & A3,A16 \\
\hline 21 & 21 Desember 2019 & A4,A29,A19 \\
\hline 22 & 22 Desember 2019 & A14,A26,A28,A10 \\
\hline 23 & 23 Desember 2019 & A4,A7,A4 \\
\hline 24 & 24 Desember 2019 & A19,A21,A6 \\
\hline 25 & 25 Desember 2019 & A4,A4,A14 \\
\hline 26 & 26 Desember 2019 & A30,A5,A13 \\
\hline 27 & 27 Desember 2019 & A12,A2,A4 \\
\hline 28 & 28 Desember 2019 & A2,A6 \\
\hline 29 & 29 Desember 2019 & A4,A4 \\
\hline 30 & 30 Desember 2019 & A29,A9 \\
\hline 31 & 31 Desember 2019 & A13,A17,A11 \\
\hline
\end{tabular}

\subsubsection{Frekuensi dan support tiap item.}

Dari tabel 3.2 dengan diberikan minum support dari 31 transaksi, frekuensi dan support item barang diurutkan dari data yang paling tinggi kemudian dilakukan pencarian nilai support item dengan rumus :

$$
\text { Support }(\mathrm{A})=\frac{\text { Jumlah Transaksi mengandung Transaksi }(A)}{\text { Total Transaksi }} \times 100 \%
$$

Berdasarkan rumus diatas maka akan didapat nilai support $=10 \%$. seperti pada tabel 3.5 berikut ini :

Tabel 3.5 Data transaksi memenuhi minimum support

\begin{tabular}{|c|l|l|}
\hline TID & \multicolumn{1}{|c|}{ Tanggal } & \multicolumn{1}{c|}{ Transaksi } \\
\hline 1 & 01 Desember 2019 & A13,A2 \\
\hline 2 & 02 Desember 2019 & A2,A4 \\
\hline 3 & 03 Desember 2019 & A4,A2,A19,A5 \\
\hline 4 & 04 Desember 2019 & A13,A29 \\
\hline 5 & 05 Desember 2019 & - \\
\hline 6 & 06 Desember 2019 & A2,A28 \\
\hline 7 & 07 Desember 2019 & A19,A19 \\
\hline 8 & 08 Desember 2019 & A2 \\
\hline
\end{tabular}




\begin{tabular}{|c|l|l|}
\hline 9 & 09 Desember 2019 & A13,A2 \\
\hline 10 & 10 Desember 2019 & A4,A12,A2 \\
\hline 11 & 11 Desember 2019 & A12,A2,A28,A13 \\
\hline 12 & 12 Desember 2019 & A28,A2,A4 \\
\hline 13 & 13 Desember 2019 & A12,A2 \\
\hline 14 & 14 Desember 2019 & A2,A13 \\
\hline 15 & 15 Desember 2019 & A28,A4,A2 \\
\hline 16 & 16 Desember 2019 & A4,A13 \\
\hline 17 & 17 Desember 2019 & A2 \\
\hline 18 & 18 Desember 2019 & A29 \\
\hline 19 & 19 Desember 2019 & A5 \\
\hline 20 & 20 Desember 2019 & - \\
\hline 21 & 21 Desember 2019 & A4,A19 \\
\hline 22 & 22 Desember 2019 & A28 \\
\hline 23 & 23 Desember 2019 & A4 \\
\hline 24 & 24 Desember 2019 & - \\
\hline 25 & 25 Desember 2019 & A4 \\
\hline 26 & 26 Desember 2019 & A5,A13 \\
\hline 27 & 27 Desember 2019 & A12,A2,A4 \\
\hline 28 & 28 Desember 2019 & A2 \\
\hline 29 & 29 Desember 2019 & A4 \\
\hline 30 & 30 Desember 2019 & A29 \\
\hline 31 & 31 Desember 2019 & A13 \\
\hline
\end{tabular}

\subsubsection{Pembentukan FP-Tree.}

Gambar dibawah ini memberikan ilustrasi mengenai pembentukan FP-Tree dari tabel 3.5 data transaksi yang telah memenuhi minimum support.

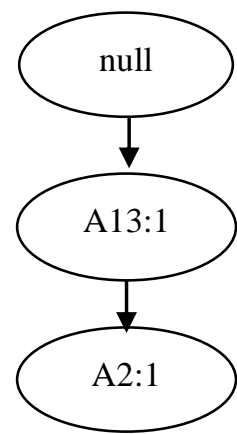

Gambar 3.1 Hasil Pembentukan FP-Tree Setelah Pembacaan TID 1 


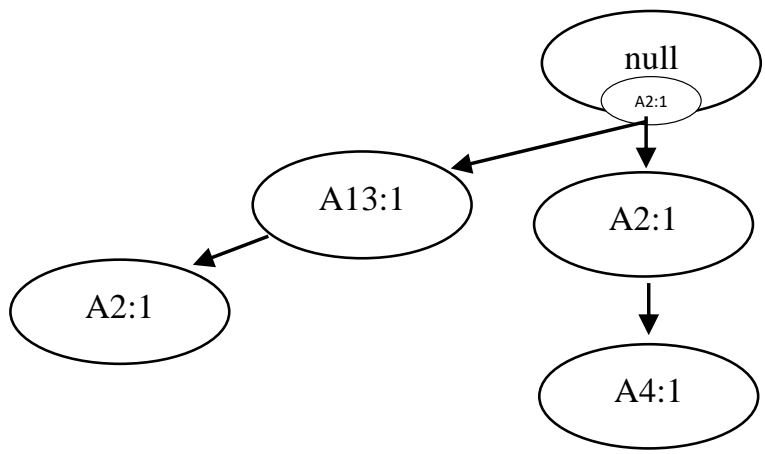

Gambar 3.2 Hasil Pembentukan FP-Tree Setelah Pemba TID 2

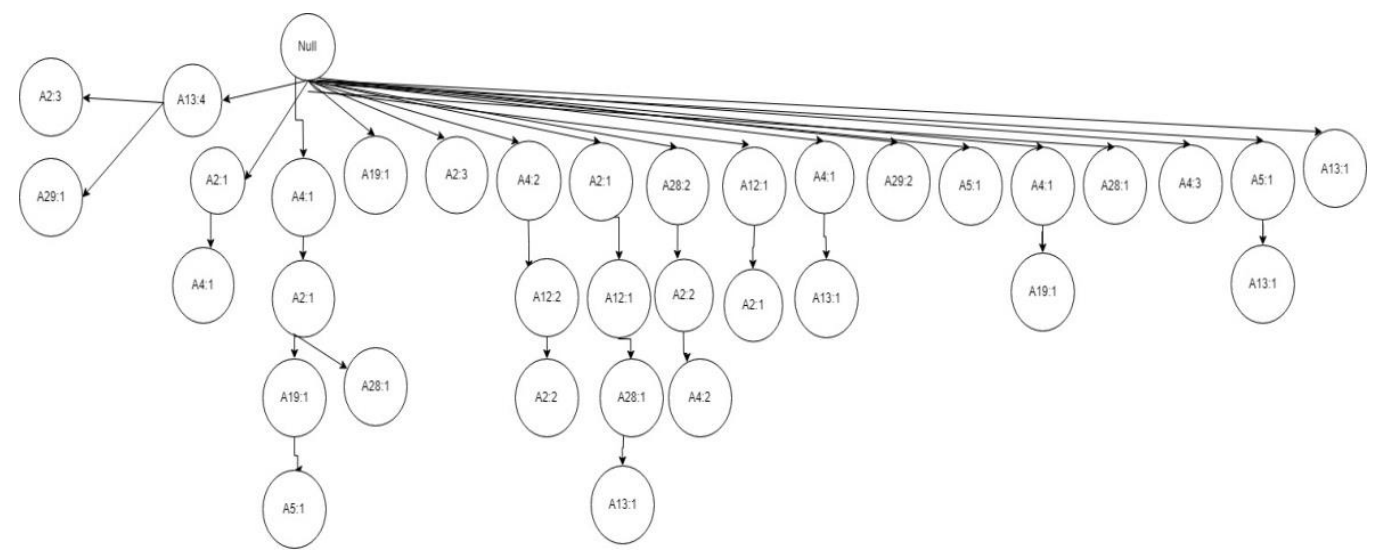

Gambar 3.31 Hasil Pembentukan FP-Tree Setelah Pembacaan TID 31

Setelah tahapan pembentukan FP-Tree dari data transaksi, akan diterapkan algoritma FP-Growth. Conditional pattern base merupakan subdatabase yang berisi prefix path (lintasan prefix) dan suffix (pola akhiran). Pembangkit conditional pattern base didapatan melalui FP-Tree yang telah di bangun sebelumnya. Untuk menemukan frequent itemset dari tabel 3.5, maka terlebih dulu ditentukan lintasan yang berakhiran dengan support count terkecil hingga yang terbesar yaitu, $(A 29)=5,(A 12)=5,(A 19)=6,(A 28)=6,(A 5)=8,(A 13=9,(A 4=12, A 2=13$. Frequent Itemset seperti yang ditampilkan pada tabel berikut :

Tabel 3.6 Hasil Frequent Itemset

\begin{tabular}{|l|l|}
\hline \multicolumn{1}{|c|}{ Suffix } & \multicolumn{1}{c|}{ Subset } \\
\hline A12 & - \\
\hline A29 & $(\mathrm{A} 2, \mathrm{~A} 13: 3),(\mathrm{A} 13: 1)$ \\
\hline A19 & $(\mathrm{A} 4: 1)$ \\
\hline A28 & $(\mathrm{A} 2: 2),(\mathrm{A} 4: 1)$ \\
\hline A5 & $(\mathrm{A} 19, \mathrm{~A} 2, \mathrm{~A} 28, \mathrm{~A} 4: 1)$ \\
\hline \multicolumn{2}{|c|}{} \\
\hline A13 & $(\mathrm{A} 28, \mathrm{~A} 2, \mathrm{~A} 2, \mathrm{~A} 4, \mathrm{~A} 5: 1)$ \\
\hline A4 & $(\mathrm{A} 2, \mathrm{~A} 28: 2),(\mathrm{A} 2: 1)$ \\
\hline A2 & $(\mathrm{A} 12, \mathrm{~A} 4: 2),(\mathrm{A} 29: 1),(\mathrm{A} 13: 4),(\mathrm{A} 2: 1)$ \\
\hline
\end{tabular}

\subsubsection{Pembentukan Association Rule.}

Pada tahap ini digunakan untuk menentukan nilai minimum support dan minimum confidence pada tiap itemset dengan rumus sebagai berikut :

a. Minimum support. 
Pada tahap ini digunakan untuk menentukan nilai minimum support $=9 \%$ pada tiap itemset dengan rumus sebagai berikut :

Support $(A)=$, Lumlah Transaksi yang mengandung A dan $\times 100 \%$

Total Transaksi

b. Minimum confidence

Pada tahap ini digunakan untuk menentukan nilai minimum confidence $=30 \%$ pada tiap itemset dengan rumus sebagai berikut :

Support $(A)=$, Lumlah Transaksi yang mengandung $A, \quad \times 100 \%$

Total Transaksi mengandung nilai $\mathrm{A}$

Setelah nilai setiap itemset diketahui dalam pola perhitungan, maka dilakukan pengelompokan nilai support dan nilai confidence pada tiap transaksi untuk mengetahui nilai tertinggi, sebagi berikut :

Tabel 3.10 Hasil Association Rule

\begin{tabular}{|c|c|c|c|c|}
\hline TID & Frequent Pattern & Frekuensi & Support & Confidence \\
\hline 1 & $\mathrm{~A} 2, \mathrm{~A} 29$ & 4 & $(4 / 31) \times 100 \%=12,90 \%$ & $(4 / 7) \times 100 \%=57,14 \%$ \\
\hline 2 & $\mathrm{~A} 13, \mathrm{~A} 29$ & 4 & $(4 / 31) \times 100 \%=12,90 \%$ & $(4 / 7) \times 100 \%=57,14 \%$ \\
\hline 3 & $\mathrm{~A} 13, \mathrm{~A} 2$ & 4 & $(4 / 31) \times 100 \%=12,90 \%$ & $(4 / 7) \times 100 \%=57,14 \%$ \\
\hline 4 & $\mathrm{~A} 4, \mathrm{~A} 28$ & 3 & $(3 / 31) \times 100 \%=9,67 \%$ & $(3 / 7) \times 100 \%=42,85 \%$ \\
\hline 5 & $\mathrm{~A} 2, \mathrm{~A} 4$ & 3 & $(3 / 31) \times 100 \%=9,67 \%$ & $(3 / 7) \times 100 \%=42,85 \%$ \\
\hline
\end{tabular}

Dari tahapan yang telah dilakukan , maka aturan asosianya adalah sebagai berikut :

1. Dengan membeli cincin putar (A2) maka akan membeli mainan kalung (A29) dengan nilai support $=12,90 \%$ dan nilai confidence $=57,14 \%$.

2. Dengan membeli kalung nama (A13) maka akan membeli mainan kalung (A29) dengan nilai support $=12,90 \%$ dan nilai confidence $=57,14 \%$.

3. Dengan membeli kalung nama (A13) maka akan membeli cincin putar (A2) dengan nilai support $=12,90 \%$ dan nilai confidence $=57,14 \%$.

4. Dengan membeli cincin rantai pilin (A4) maka akan membeli anting (A28) dengan nilai support $=9,67 \%$ dan nilai confidence $=42,85 \%$.

5. Dengan membeli cincin putar (A2) maka akan membeli cincin rantai pilin (A4) dengan nilai support $=9,67 \%$ dan nilai confidence $=42,85 \%$.

\section{PENGUJIAN DAN IMPLEMENTASI}

4.1 Tampilan Form Login.

Form Login digunakan untuk mengamankan sistem dari user-user yang tidak bertanggung jawab sebelum masuk ke Form halaman utama. Berikut adalah tampilan Form Login :

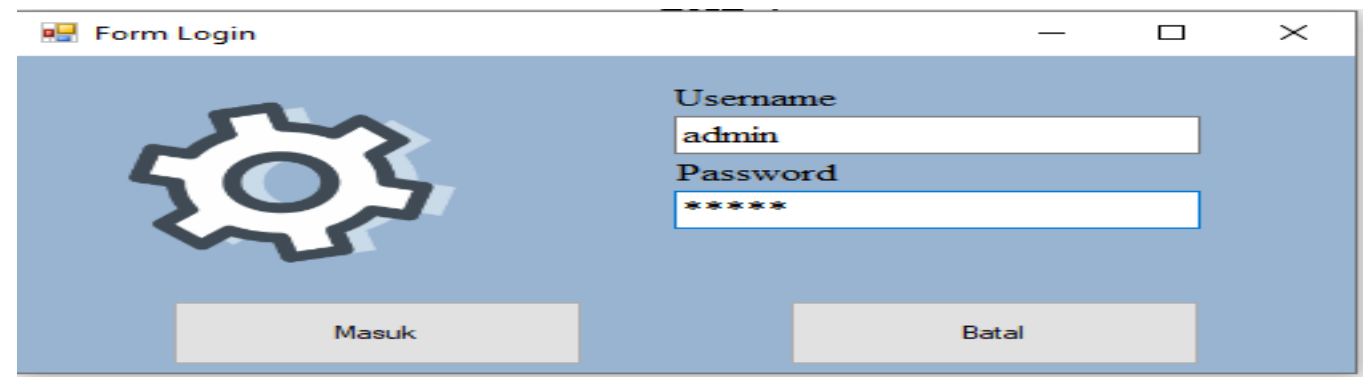

Gambar 5.1 Form Login

\subsection{Tampilan Form Halaman Utama}

Form Halaman Utama digunakan sebagai penghubung untuk Form Data Item, Form Transaksi proses metode dan ada beberapa Form lainnya salah satunya ada Form Keluar bertujuan untuk mengakhiri program secara keseluruhan.adalah sebagai berikut : 


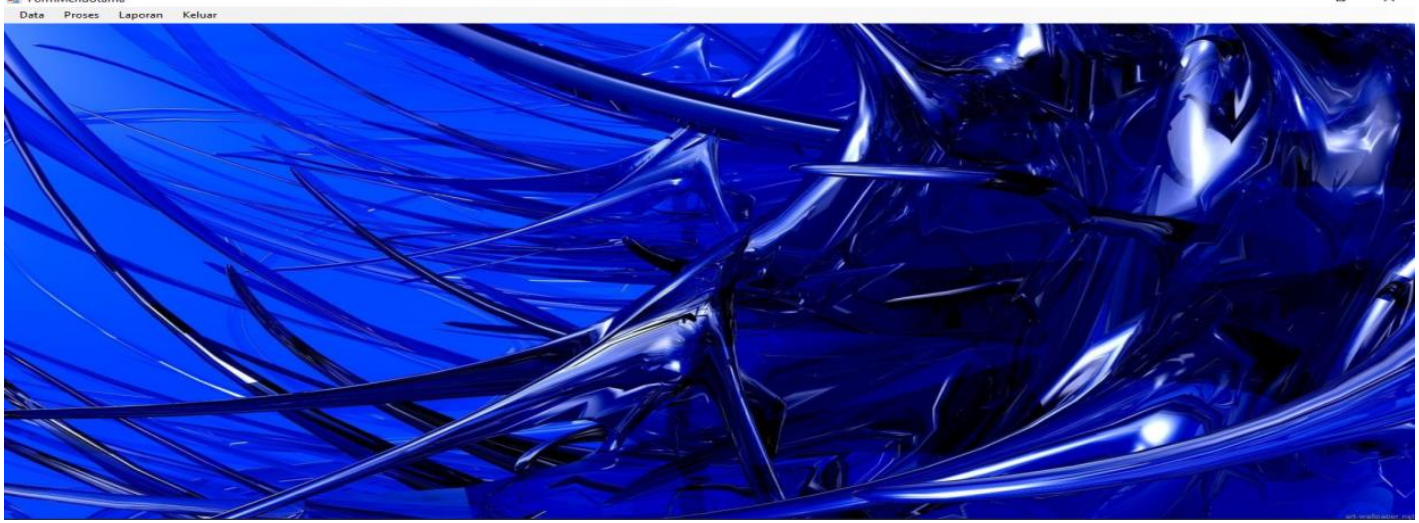

Gambar 4.2 Form Halaman Utama

\subsection{Tampilan Form Data Item}

Form Data Item adalah Form yang berfungsi untuk mengolah data tentang item dengan jumlah item pada toko emas yang dimiliki. Berikut adalah tampilan Form data Item.

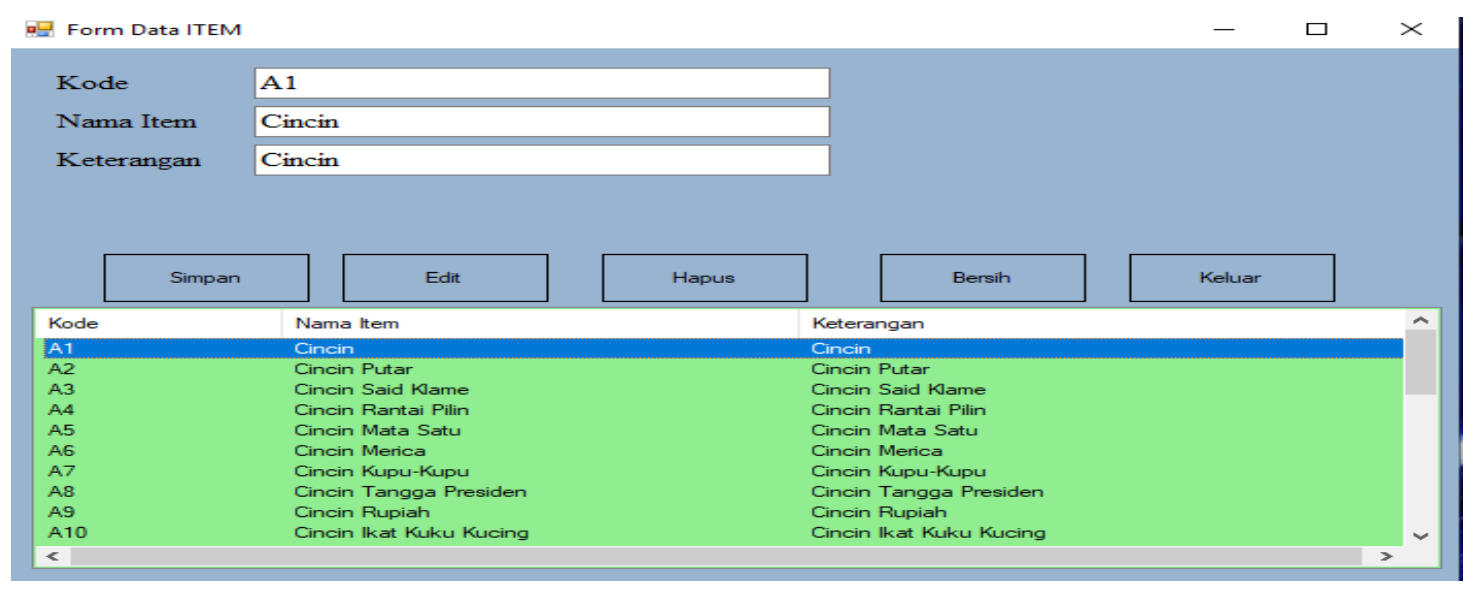

Gambar 4.3 Form Data Item

\subsection{Tampilan Form Data Transaksi}

Form Data Item adalah Form yang berfungsi untuk mengolah data tentang transaksi penjualan pada toko emas dan perak Adi Saputra Tanjung yang dimiliki. Berikut adalah tampilan Form data Item.

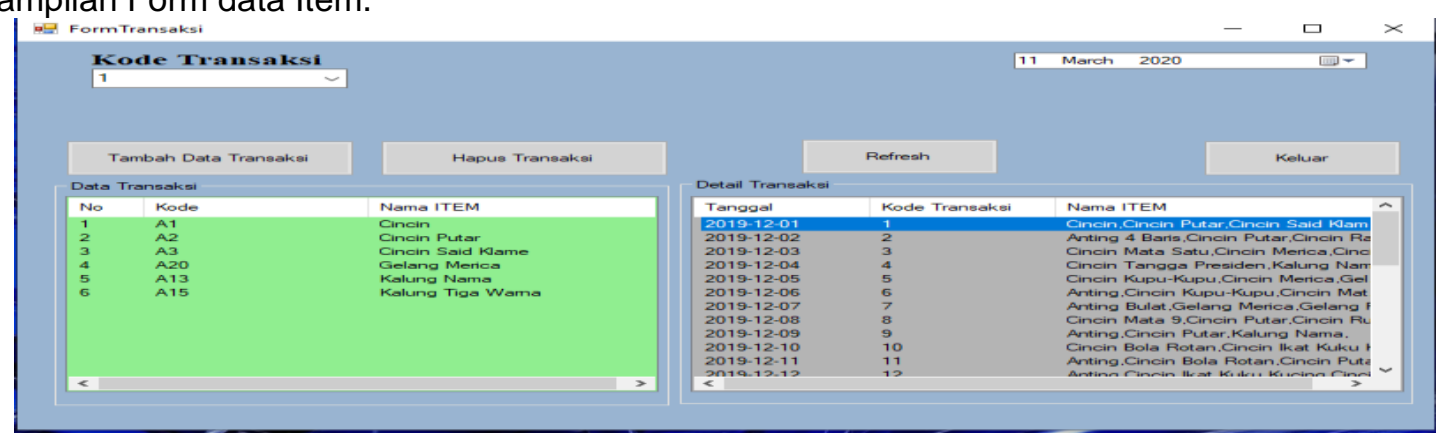

Gambar 4.4 Form Data Transaksi

\subsection{Tampilan Form Proses FP-Growth.}

Form proses berisi data perhitungan menggunakan algoritma FP-Growth pada data transakasi pembelian perak. Bentuk rancangan form proses dapat dilihat pada gambar dibawah ini : 


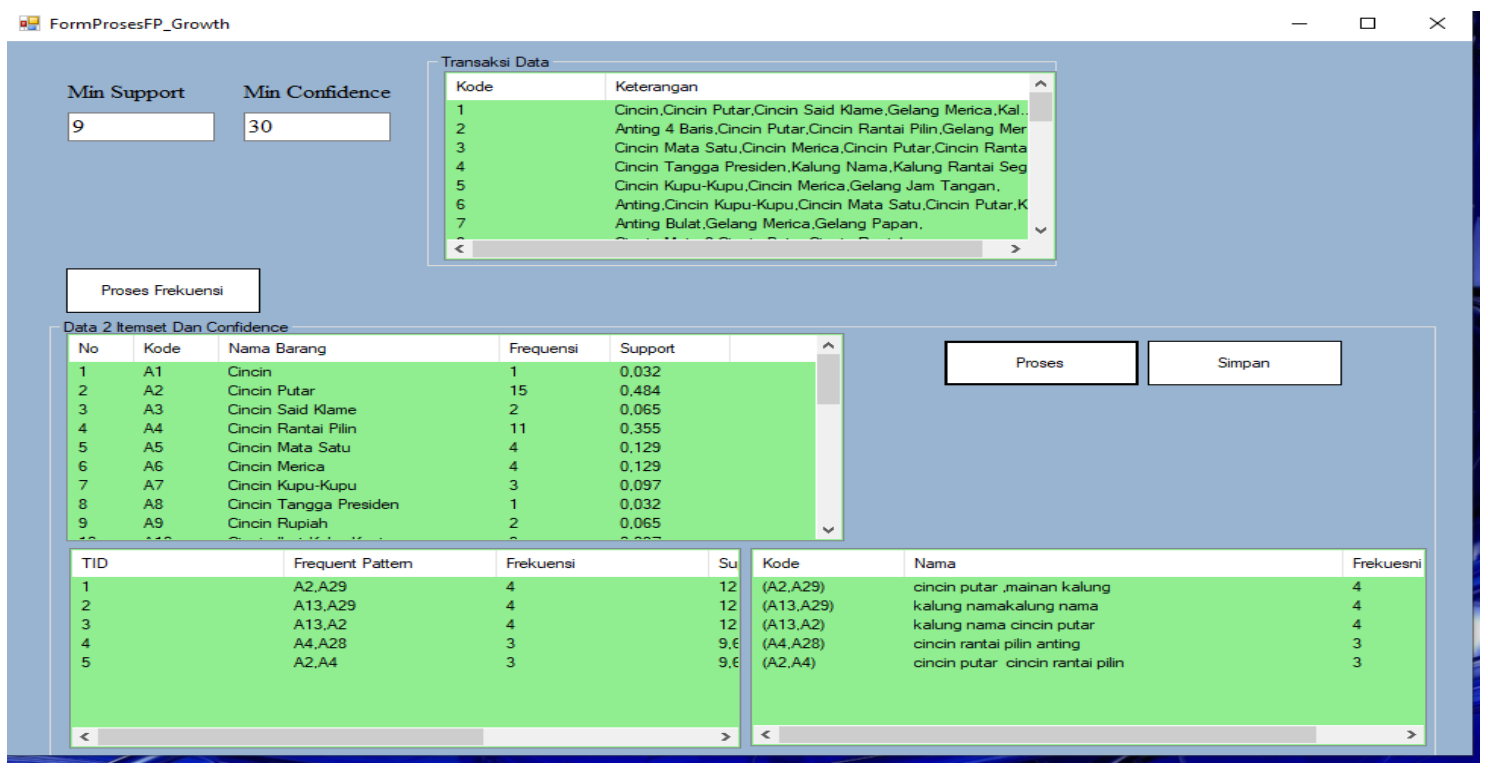

Gambar 4.5 Form Proses FP-Growth.

\subsection{Laporan Proses Hasil FP-Growth}

Laporan Proses FP-Growth merupakan hasil pengelompokan item set toko emas yang menampilkan hasil perhitungan metode FP-Growth sebagai berikut :

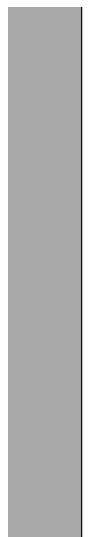

\begin{tabular}{|c|c|c|c|c|}
\hline \multicolumn{5}{|c|}{$\begin{array}{c}\text { TOKO EMAS DAN PERAK ADI } \\
\text { SAPUTRA TANJUNG } \\
\text { Jalan Nauli LK IV Pusat Pasar Gunung Tua }\end{array}$} \\
\hline & \multicolumn{3}{|c|}{ Hasil aturan asosianya } & \\
\hline № & KODE & Freq & Support & Conf \\
\hline 1 & $\mathrm{~A} 2, \mathrm{~A} 29$ & 4 & 12,90 & 57,14 \\
\hline 2 & A.13,A29 & 4 & 12,90 & 57,14 \\
\hline 3 & $\mathrm{~A} 13, \mathrm{~A} 2$ & 4 & 12,90 & 57,14 \\
\hline 4 & $\mathrm{~A} 4, \mathrm{~A} 28$ & 3 & 9,67 & 42,85 \\
\hline 5 & $\mathrm{~A} 2, \mathrm{~A} 4$ & 3 & 9,67 & 42,85 \\
\hline
\end{tabular}

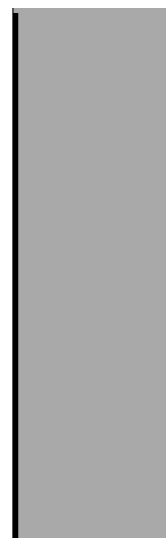

Gambar 4.6 Laporan Proses Hasil FP-Growth.

\section{KESIMPULAN}

Berdasarkan hasil penelitian ini, dapat disimpulkan beberapa hal mengenai sistem keamanan kebocoran gas menggunakan teknik simplex.

1. Rancang bangun ini dirancang menggunakan sensor MQ6 sebagai deteksi gas yang nantinya akan diproses oleh arduino uno sehingga menghasilkan peringatan berupa pesan.

2. Untuk menerapkan komunikasi searah dalam memberikan peringatan kebocoran gas menggunakan modul GSM pada rancang bangun ini diterapkanlah teknik simplex yang akan bekerja berdasarkan input system sensor gas MQ6.

3. Penerapan motor servo digunakan saat sensor gas yang merupakan input mendeteksi adanya kebocoran kebakaran 


\section{REFERENSI}

[1] I. Kurniaty and $\mathrm{H}$. Hermansyah, "POTENSI PEMANFAATAN LPG (LIQUEFIED PETROLEUM GAS) SEBAGAI BAHAN BAKAR BAGI PENGGUNA KENDARAAN BERMOTOR," 2016.

[2] L. I. Ramadhan, D. Syauqy and B. H. Prasetio, "Sistem Pendeteksi Kebocoran Gas LPG Menggunakan Metode Fuzzy yang Diimplementasikan dengan Real Time Operating System (RTOS)," 2017.

[3] E. P. Zelvia, "KARAKTERISASI SENSOR GAS LIQUEFIED PETROLEUM GAS (LPG) DARI BAHAN SEMIKONDUKTOR HETEROKONTAK CUO/CUO(TIO2)," JIF), vol. 9, 2017.

[4] H. Setiadi, P. Alat, R. Ananda and M. Ardiansyah, "Perancangan Alat Pendeteksi Kebocoran Tabung Gas LPG Dengan Menggunakan Sensor MQ-6 Untuk Mengatasi Bahaya Kebakaran," 2019.

[5] M. Ferdian Putra, A. Harsa Kridalaksana, Z. Arifin and P. Studi Ilmu Komputer FKTI Universitas Mulawarman JI Barong Tongkok Kampus Gunung Kelua Kota Samarinda, "RANCANG BANGUN ALAT PENDETEKSI KEBOCORAN GAS LPG DENGAN SENSOR MQ-6 BERBASIS MIKROKONTROLER MELALUI SMARTPHONE ANDROID SEBAGAI MEDIA INFORMASI," Jurnal Informatika Mulawarman, vol. 12, no. 1, p. 1, 2017.

[6] Rizala, Abdul Muida* and Iklas Sanubarya, "Perbandingan Kinerja Sensor TGS2610, MQ2, dan MQ6 pada Alat Pendeteksi Kebocoran Tabung Liquified Petroleum Gas (LPG) Menggunakan ATMega2560," vol. 7, 2019.

[7] Adrian Simon Burhan1, Muljono1 and dan Eko Syamsuddin2, "ALAT PENCEGAHAN KEBAKARAN YANG DISEBABKAN KEBOCORAN LIQUEFIED PETROLEUM GAS (LPG)," vol. 15, 2018.

[8] [1]Rian Affrilianto, [2]Dedi Triyanto and [3]Suhardi, "RANCANG BANGUN SISTEM PELACAK KENDARAAN BERMOTOR MENGGUNAKAN GPS DENGAN ANTARMUKA WEBSITE," vol. 5, 2017.

[9] H. Amri and T. Elektro Politeknik Negeri Bengkalis Jln Bathin Alam Sungai Alam Bengkalis Riau, "Multitek Indonesia: Jurnal Ilmiah Sistem Monitoring Arus Dan Tegangan Menggunakan SMS Gateway," no. 13, pp. 1907-6223, 2019. 